\title{
When a Pandemic Strikes the Vineyard: Searching for the Meaning of Pastoral Care During COVID-19
}

\author{
Hee-Kyu Heidi Park ${ }^{1}$ (D) Eonkyeong Lee ${ }^{1}$
}

Accepted: 27 December 2021 / Published online: 12 January 2022

(c) The Author(s), under exclusive licence to Springer Science+Business Media, LLC, part of Springer Nature 2022

\begin{abstract}
A student asked, "What is pastoral care amid the COVID-19 pandemic?" The student and the professor embarked on a conversational journey to explore the layers of suffering during the pandemic that prompted the question and to interpret the neoliberal characteristics of the relational pains in the experience. Through the participatory case study of this conversation, this article puts the pandemic experience of the student in dialogue with the Matthean passage on the vineyard workers to expose the limits of the neoliberal rationality that feeds into the suffering during the pandemic. The ensuing theological reflection culminates in a conversation about the understanding of the Matthean evil eye, Emmanuel Levinas's understanding of the face, and Bruce Roger-Vaughn's concept of third-order suffering. The reflection concludes with an answer to the question about pastoral care during COVID-19.
\end{abstract}

Keywords COVID-19 $\cdot$ Bible $\cdot$ Neoliberalism $\cdot$ Shame $\cdot$ Family $\cdot$ Evil eye $\cdot$ Face $\cdot$ Hope . Levinas $\cdot$ Third-order suffering

\section{Introduction}

The South Korean experience of the COVID-19 pandemic in 2020 did not involve a lockdown, unlike in many other countries. The pandemic was handled with the centralized tracking of the virus transmission through rigorous testing and information control with open borders to allow international trade to sustain the nation's economic activities. The very beginning of the pandemic period was chaotic, with a shortage of masks and a citywide breakout of the virus in one of the southern cities. The death rate was mostly well controlled due to the detailed information on the pandemic available to the public, which allowed the citizens to learn the effectiveness of mask-wearing and social distancing. Quarantines happened both voluntarily and by government mandate when triggered by possible contact with a COVID-19 patient or transmitter, but parts of the market remained open for

Hee-Kyu Heidi Park

heekyu.park@ewha.ac.kr

Eonkyeong Lee

mouadonai@ewhain.net

1 Christian Studies Department, Ewha Womans University, Humanity Building 319, 52

Ewhayeodae-gil, Seodaemun-gu, Seoul 03760, Republic of Korea 
face-to-face interaction with various safety measures in place. However, the constraints of the pandemic were tangibly felt throughout the society. Social distancing and quarantining translated into inescapable economic distress. Entrepreneurship became fragile due to the unstable economy, and small businesses constantly disappeared. Even formerly bustling college campus areas had their fair share of deserted storefronts.

Quarantining and social distancing rendered many things invisible — suffering was also quarantined. It was primarily inferred by the invisibility and absence of people in the emptied-out spaces. The pandemic isolated people in their homes, in their workplaces, and behind their masks. Despite the deep sense of isolation that social distancing protocols inevitably created, I (the first author, Heidi) felt privileged. I was able to teach my students from my private office without experiencing the financial blows others had to overcome. I had to speculate about the pain that many others were going through, but their pain was undetectable from where I sat. The media talked about the corona blues, but I felt insufficiently informed to talk about it with expertise. Whatever I experienced in the pandemic seemed minor compared to what the invisibility seemed to signify.

Then, one day in the late summer of 2020, my student Eonkyeong (the second author) contacted me to ask, "What on earth is pastoral care amid the COVID-19 pandemic?"1 Her sense of urgency poignantly exposed my location, where I felt sheltered by the security of my academic job in a major university. My helplessness as a caregiver, stemming from the shame I felt for my distance from the suffering that the pandemic was causing for many, met hers. We explored the pain behind the question in our conversation. Her core question signaled a deep sense of ambiguity, which warranted deeper processing. Could writing a paper together become a form of care? I asked her if she would meet me regularly online to dialogue and turn our conversation into an article. Thus, we started a caregiving conversation that lasted from August to November 2022 that started with an unconventional premise: the goal to expose the content of the conversation instead of keeping confidentiality.

By describing the interpretive process in the caregiving conversation regarding Eonkyeong's experience during the pandemic, this article aims to expose the dehumanizing neoliberal suffering amidst the COVID-19 pandemic and find the possibility of hope that sustains human relationships in the difficult time. As a case study, it answers the following research question: What does Eonkyeong's experience reveal about the character of care in the prolonged time of the pandemic? As a pastoral theological work, this study allowed us to answer Eonkyeong's question about pastoral care through our resulting theological reflection.

\section{Methods}

\section{Participatory case study}

This work is a participatory case study of the conversation between the first author (cisgender woman in her $40 \mathrm{~s}$ ) and the second author, Eonkyeong (cisgender woman in her late $20 \mathrm{~s}$ ), about Eonkyeong' experience. As the study's object, or the case, is our conversation,

\footnotetext{
${ }^{1}$ Our location is one of the major universities in Seoul, South Korea. The first author's field is practical theology and pastoral care and counseling. The second author is an MA student in pastoral care and counseling.
} 
not simply Eonkyeong's experience, the theological reflections resulting from our dialogue are also part of the case. Our mutuality generated both active imaginations based on our empathic listening and strong impetuses to make sense of the ambiguous suffering that Eonkyeong experienced. As a caregiving conversation, ours was unusual as it combined active theological reflection, biblical interpretation, and research in the literature to advance our process of searching for meaning. On the other hand, as a participatory case study, this process demonstrates the characteristics of participatory research, which is "fundamentally conceptualized as a social action, change-oriented methodology" (Reilly, 2010, p. 659). Through our conversation, we aimed to walk together to process the difficulties posed by the COVID-19 pandemic. The power differentials between a professor and a student persisted. However, Eonkyeong remained the possessor of the expert knowledge of her own experience, constantly assessing the validity of the interpretation that our conversation generated. Thus, "[T]he formal boundaries between the traditional roles (researchersubject/participant, knowledge producer-knowledge consumer, etc.) are reduced or eliminated in favor of a variety of interchangeable egalitarian roles," as Reilly points out (2010, p. 659). As such, a participatory case study values "critical subjectivity and reflexivity" (Reilly, 2010, p. 659) more than objectivity. In our case, both of us were research participants and researchers at the same time. Observation, interpretation, and reflection constantly flowed back and forth in our relationship.

\section{The process}

We met regularly for ten sessions. Some of our meetings were virtual, while some were in person. We followed the social-distancing protocols of wearing marks and sitting two meters apart when we met in person. For added security, we had an acrylic screen between us. ${ }^{2}$ In each conversation, Eonkyeong told her stories, and I asked questions. She reflected back. When the questions provided a direction, we did research. Then, we came back with a reflection on the materials we had read and talked about how the new perspective helped her navigate through her life situation and how it was limiting. This article describes what we gleaned from our conversations, which led us to articulate the core value of our discipline.

\section{The role of the bible}

The Bible had an important place in our interpretive process. As Park (2014) has explored in her phenomenological studies of ardent Bible readers' experiences of transformation motivated through reading the Bible, those who have developed a relationship with the Bible experience it as a subject. The transformative moments in their engagement with the subjectivity of the Bible are experienced in times when they feel deeply empathized by the subjectivity of the Bible. ${ }^{3}$ As Eonkyeong's religious formation had taken place in a very

\footnotetext{
2 South Korea did not have lockdowns during the pandemic in 2020 but did have government-led tiered social-distancing measures. Mobility was always possible, but gathering was restricted based on the severity of the pandemic.

${ }^{3}$ For example, a profound change in perspective happened when the mother of a boy who had been born blind and deaf was struggling with the question "Why me? Why us?" and encountered John 9:1-3 anew. Jesus' disciples asked, "Rabbi, who sinned, this man or his parents that he was born blind?" Jesus answered, "Neither this man nor his parents sinned; he was born blind so that God's work might be revealed in him." In this passage, the mother found a deeply empathizing voice of the subjectivity of the Bible that spoke piercingly to her experience. This is an example of one pattern of such a transformation that Park's research participants articulated.
} 
conservative Protestant church where she had cultivated a long relationship with the Bible, I asked what Bible passage came to her mind that reflected her experiences. This passage, the parable of the vineyard from Matthew, began to frame our conversation. Eventually, we decided to present our results by framing our reflection according to the flow of the biblical passage.

\section{Translation}

Another element of the method we used was the process of translation. All conversations happened in our mother tongue, Korean, whereas our bibliographic research was done in both Korean and English. Eonkyeong would write up her reflections in Korean and I translated them into English, weaving our interpretation into the translation. We often noted how the linguistic transformation of our reflection provided a distance and a fresh perspective on our experiences. The translation process forced us to articulate concepts that we had glanced over in our mother tongue. Thus, the articulation in another language functioned as a mirror through which our optics gained a more vibrant, sharper resolution.

\section{Results}

Our conversation initially focused on Eonkyeong's relationship with her father in her formation process, but it soon reached the subject of her current work situation. Her father's unemployment resulted in anxiety and urgency that burdened her tremendously. As we explored her experience, I asked if any biblical passage came to her mind. The parable of the laborers in the vineyard that Jesus used to explain the kingdom of heaven was troubling her. So, we decided to engage the passage:

'For the kingdom of heaven is like a landowner who went out early in the morning to hire laborers for his vineyard. After agreeing with the laborers for the usual daily wage, he sent them into his vineyard. When he went out about nine o'clock, he saw others standing idle in the marketplace; and he said to them, "You also go into the vineyard, and I will pay you whatever is right." So they went. When he went out again about noon and about three o'clock, he did the same. And about five o'clock he went out and found others standing around; and he said to them, "Why are you standing here idle all day?" They said to him, "Because no one has hired us." He said to them, "You also go into the vineyard." When evening came, the owner of the vineyard said to his manager, "Call the laborers and give them their pay, beginning with the last and then going to the first." When those hired about five o'clock came, each of them received the usual daily wage. Now when the first came, they thought they would receive more; but each of them also received the usual daily wage. And when they received it, they grumbled against the landowner, saying, "These last worked only one hour, and you have made them equal to us who have borne the burden of the day and the scorching heat." But he replied to one of them, "Friend, I am doing you no wrong; did you not agree with me for the usual daily wage? Take what belongs to you and go; I choose to give to this last the same as I give to you. Am I not allowed to do what I choose with what belongs to me? Or are you envious because I am generous?" So the last will be first, and the first will be last.' (Matthew 20:1-16 NRSV)

This passage's focus on labor and wages generated a rich yet painful conversation around the challenging economic reality that the COVID-19 pandemic had intensified. In South 
Korea, general economic activities did not halt with lockdowns but continued with strict social-distancing measures that limited the size of social gatherings and opening hours of establishments, preserving economic activities, albeit to a very limited extent. With rather well-managed centralized pandemic control, suffering from the disease itself, such as hospitalizations and deaths, was not as tangible as was reported in other countries. Instead, the neoliberal market continued to function, although in a deformed structure caused by the pandemic, and the economic suffering stemming from pandemic management became the focal point of the pandemic reckoning. The results of our reflections thus parse the layers of the suffering exacerbated by this reality through Eonkyeong's narrative, which we have arranged according to the sequence in the Matthew passage because, as we unpacked it, new questions arose.

COVID-19 strikes the meritocratic neoliberal world

"These last worked only one hour, and you have made them equal to us who have borne the burden of the day and the scorching heat."

-Matthew 20:12 NRSVA

I (Eonkyeong) became the head of the household once my family exhausted its savings after my father had lost his job four years earlier. I had to take two semesters off to support my family. In the lean job market affected by COVID-19, I found an insurance company that offered a minimum-wage position, after three months of searching. Due to an earlier back injury from a traffic accident, I had to limit my search to office jobs. My department was mostly composed of vulgar young female high school graduates. The workload was inhumane. One day my boss, who was dating the much-older branch manager, added her workload to mine. I asked, "Is this also my responsibility?" She must have told the branch manager, as he ordered me to pack up and leave at the end of the month. Unable to find a replacement for me, he called me back. I took this as an opportunity to negotiate for vacation time, which is legally mandated but was not practiced in this company. A rigid hierarchy was maintained through age and gender dynamics, as well as through exposure to vulnerability, which the pandemic underscored; those at the top wore masks, while those at the bottom did not out of fear of seeming judgmental of others. I, nonetheless, decided to wear a mask to safeguard myself, which prompted my co-workers to rethink ways to protect themselves.

In this predatory company, which Eonkyeong would not have joined before COVID-19, the "losers" in the competitive educational system were strategically gathered as optionless laborers. This strict disciplinary hierarchy kept older men on top and young women at the bottom. Some female managers mingled the two tiers through their austere authority and strategic connections to power. Some of their strategies were sexualized, which added to Eonkyeong's perception of the company as predatory. Lacking options for fear of losing their job, this gendered group of high school graduates was not even empowered to protect themselves from the pandemic by wearing masks indoors.

Entering this environment out of necessity, Eonkyeong was an oddity. While she had had her share of hardships, she had always strived for more education, accumulating merits through new skill sets and qualifications. She initially thought her colleagues had ended up there because they did not invest in themselves and, thus, deserved to be there in this meritocratic society. To decipher the cultural codes of this unfamiliar world, Eonkyeong distanced herself, distinguishing herself from them, which led her to read the vineyard parable with empathy for those who had worked all day in the vineyard. Wasn't their demand reasonable? Shouldn't the amount of labor translate into a proportionate compensation? 
Why did this vineyard owner's treatment sound more like injustice than compassion? These meritocratic thoughts quickly put her into a dilemma.

She felt cornered in this company, and she had another dark cloud hovering over her head. Her career-driven father was used to providing well for his family. He was presumably a winner in the meritocracy, but he had been unemployed for four years, putting his family on government assistance. This dilemma revealed conflicting moral principles operating underneath the surface.

First, an obvious line of logic conflicted with the message of the vineyard parable. The passage did not blame the workers' for coming late to work, contradicting the sense of justice of the early-arriving laborers and of Eonkyeong. All workers were rewarded equally, but for those who expected proportionate compensation, this equity betrayed justice. Searching for the emotional language behind this, we realized the morality stemming from this justice called for a sense of shame.

Fine-tuning this, Eonkyeong she found two strands of shame. The first was the shame she initially felt justified putting on those who had failed to come early to the vineyard or who had failed to power through the education system. She felt the other strand of shame precisely because she put the shame on them. Behind the first shame lay the weighty responsibility of each individual to do their best in the market. Reflecting on the second shame that she placed on her young, uneducated co-workers, Eonkyeong realized she was also putting that shame on her father; he should be ashamed for failing to provide for his family.

\section{Failure to be employed}

"Why are you standing here idle all day?" They said to him, "Because no one has hired us."

-Matthew 20:6b-7a NRSVA

My [Eonkyeong's] father used to be a successful high-ranking officer in an international shipbuilding and offshore engineering company. When an oil crisis hit his field, he lost his job. Then COVID-19 followed. It was painful to watch his savings from his life's work disappear while he stayed home. In his 50s, his age became burdensome; he was regarded as too old to hire. His expertise became useless when international travels were restricted. Therefore, I, his first-born, became the head of the household of five. Suddenly, my graduate-level studies became a luxury. The predatory work environment provoked my anger, which I directed toward father. When I returned home exhausted, I would see him in bed with his smartphone. Unpaid rent, credit card, and utility bills accumulated, and I began to get calls from creditors. Frustrated, exhausted, and despairing, I began to avoid looking at my father's face. I blamed him for every decision he had ever made. His past success, our past affluence, was distant as if in dreams. I did not trust my father anymore. Relationships in our family began to break. We had no hope. Our family seemed doomed.

Eonkyeong's father was cornered as much as she was. Daily, she faced her father, who stayed home waiting for a call from any of the companies he had contacted. Despite his previous long and successful career in the field, his inability to work turned him into an utter failure that drove her to work for the predatory company. Looking him in his face became a terror that revealed the rage in her. "As my father, how can you do this to me? 
How can you smile when you rush me into this hell?" ${ }^{4}$ Regardless of the awareness of the structural causes surrounding his failure, ${ }^{5}$ the pain inflicted on the family turned him into a shame-ridden problem because of the looming sense that he should have done something to prevent the loss of his job. Underlying this blame was the sense of liberty; he could have made better choices.

However, none of these choices belonged to the present; they all belonged to the past. Just as Eonkyeong's colleagues should have studied harder to secure a better future in their school days, her father should have done something more in the past. He was in debt. Because he could not pay it off, he was being punished, and Eonkyeong was getting the brunt of it as his daughter. ${ }^{6}$

\section{Discussion: analysis of the experience}

\section{Neoliberal punishment and shame}

The punishment of debtors is deeply embedded in the neoliberal world. Davies (2016) sees neoliberalism as having developed in three stages, from combative neoliberalism (1979-89) to normative neoliberalism (1989-2008) to the current punitive neoliberalism (2008-). "The spirit of punishment" is characterized by "its post jure logic, that is, the sense that the moment of judgment has already passed, and questions of value or guilt are no longer open to deliberation" (p. 130). The wrong is done in the past without a chance for recovery, so the present bears the guilt, leaving Eonkyeong's family to blame or burden each other. Here, debt becomes the central mechanism that maintains the system. In fact, as Lazzarato (2012) notes, neoliberalism is founded on the logic of debt. ${ }^{8}$ He writes that even "the rhetoric of 'human capital' and the entrepreneur of the self has faded all the more quickly since the 2007 financial crisis," creating a new form of the "indebted man" (p. 143). The system finds its drive in the commonly shared morality that "one has to pay one's debt" in spite of its arbitrary origin (Graeber, 2014, p. 4). Thus, the moral discipline of the punitive neoliberalism discards and expels surplus humans as worthless and immoral by the imposition of debt (Sassen, 2014). Davies observes, "[U]nder punitive neoliberalism,

\footnotetext{
${ }^{4}$ It should be noted that these strong emotions were excavated through deep conversations. This was not the mode in which Eonkyeong was outwardly interacting with her father; these were the subconscious processes that she found through our exploration.

5 The expectation that the father will support the family as the patriarch comes with a psychological burden. Each financial crisis has noticeably increased the suicide rate among Korean men (Kim et al., 2011, p. 276), contrasting with the relatively stable suicide rate of women. This can be explained by the heavier burden of responsibility imposed on men by the cultural norms of patriarchy and the ensuing intrafamily problems such as disconnection, intimate violence, and divorce that lead to the extreme choice of suicide. Eonkyeong noted that for the four years of her father's unemployment, one of her biggest concerns was that he might die by suicide.

6 Sociologist Chang (2018) traces and compares the development of liberalism in South Korean society with that of other cultures and notes that in the familial liberalism paradigm found in Korean society, the economic unit is not the individual but the nuclear family.

7 Although Adam Kotsko claims the international significance of Davies' argument due to the fact that Davies is offering a British perspective, this chronology is still a very Western one. In East Asia, punitive neoliberalism had already struck the area during the Asian financial crisis of 1997.

8 Lazzarato calls the current form of economy a "debt economy.".
} 
economic dependency and moral failure become entangled in the form of debt" (p. 160). Shame is a heavy aspect of this debt.

The double layers of shame point to a double-edged sense of agency. When one blames another for what could have been, that person's capacity, and thus their freedom, to choose is assumed. Agency is simultaneously where the blame is placed and where Eonkyeong found the humanity to gaze into. First, this agency to choose functions as the ground of the moral theology shaped by neoliberalism. Kotsko (2018) identifies the bare agency as the location where demonization is allowed to happen; neoliberalism demonizes all of us ( $p$. 73). Just like the Augustinian demon that chose to rebel against God without much reason other than that he could, the bare minimum agency to choose constitutes the qualification of becoming a demon (p. 83). As an arbitrary process that "God allows to happen owing to the conceptual necessity of allowing free will," according to Kotsko, "to 'demonize' is to set someone up to fall, providing them with just the barest sliver of agency necessary to render them blameworthy"(p. 84). As Brown (2015) observes, this liberty to choose is "relocated from political to economic life" and becomes "subject to the inherent inequality of the latter and is part of what secures that inequality" (p. 41). This translates into the capitalistic game we all must play to survive. Pastoral theologian Rogers-Vaughn (2016) says the liberty to choose is now transferred to the choice to compete, resulting in "removing substantive meaning from the word 'equality,' reducing it to 'equal opportunity", (p. 134). In this game, all players were given the opportunity to play; if you lost, you made the wrong choice with your freedom, possibly to the point of expulsion into infernal hell.

\section{Facing the other's face}

Such a demonization process happened in Eonkyeong's constant refusal to look at her father's face and meet his eyes. She refused to see his failure, which had imposed his debt on her shoulders, and most importantly, she could not accept his optimism that he would work again when the situation was so bleak. When her father failed in his bread-earning role, ${ }^{9}$ her despising him turned their relationship into a Buberian I-It relationship (Buber, 1996). Similarly, in her workplace, when her young colleagues were evaluated from the merit- (education-)based perspective, they were crude, uneducated girls who, in order to survive the system, turned into girls or women at the bottom/bitches in the company's predatory hierarchy.

However, the moment this dynamic was recognized, which happened only after her father was called to Kazakhstan to work after almost five years of waiting for work, another kind of shame overwhelmed Eonkyeong. As a student of pastoral counseling, she understood this human agency as the locus of life, where growth and social transformation happens. Eonkyeong felt ashamed that she had averted her eyes from the humanness of agency, most poignantly her own father's agency that had demonstrated hope.

To work through her frustration and anger, she desperately needed to regard him in terms of an I-It relationship. If, she says, she entered into an I-Thou relationship with him, she would have to face his hope, which was unbearable for her. When hopelessness seemed the most realistic, facing his hope meant walking with him in his surreal optimism. That translated into her making a sacrifice, maybe more than she had already made. His hope

\footnotetext{
9 Note that this patriarchal expectation creates an undercurrent that mingles with the dynamics of neoliberalism.
} 
was a painful hope she needed to laboriously eke out. She desperately needed to see him as a bad father who had caused her pain to protect herself from the consequences of his optimism. She recognized that this need was strong enough to mask the simmering love underlying the pain she took on by standing in the realism her father refused. Looking at his face, she felt the need to bear a deeper responsibility that she wanted to avoid, the demand of the nakedness of his face, as Levinas (1991) would describe it (p. 75). Just as her father's helplessness stripped him of dignity in her eyes, "[T]he nakedness of the face is destituteness" (p. 75). For Eonkyeong, the demand was clear: "To recognize the Other is to recognize a hunger. To recognize the Other is to give" (p. 75).

An eschatological search for the Other beyond the neoliberal evil eye

Is it not lawful for me to do what I will with mine own? Is thine eye evil, because I am

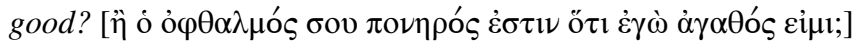

-Matthew 20:15 KJV

The vineyard parable takes an interesting turn in its conclusion with the accusation of an evil eye, according to Elliott's reading (1992, pp. 52-65). Elliott notes that fear of the evil eye and its destructive power to injure persons and communities prevailed in the ancient circumMediterranean world. Its frequent mention in the Bible makes Jesus' use of this word in this passage poignant. He reads the passage as the denouncement of "envy as incompatible with life in the kingdom of heaven and detrimental to the community's well-being" (p. 52). Ancient people regarded a whole host of people, in addition to those who were envious, as possible possessors of the evil eye: those who had unusual physical features or physical disabilities, the socially displaced, and the socially deviant, as well as strangers, exotic people, and enemies, were possibly those who suffered the most in terms of an I-It relationship with the community (p. 53). Protective measures such as "avoiding eye contact, concealing prized possessions, and denying any improvements in one's economic situation" (p. 53) may be precisely the opposite of what neoliberal consumerism requires of us who need to claim our value as human commodities in the perpetual competition in the market. When the vineyard owner's generosity is just, an envious comparison has no place. Still, in our current neoliberal world, we are structured to compare our worth as competitors in the market and blame ourselves when our value is not confirmed through employment, advancement, and consumption.

Eonkyeong faced a seemingly irreconcilable dilemma because the evil eye was not operating where she could say, "I want to have more than what my neighbor has." That is a luxury. When she asked, "What is pastoral care in the pandemic?" the following conditional phrase was, "when I don't have 20,000 won (about 18 USD) for my family's survival today." Here, in her own destitution, she saw her father as a socially displaced Other with an evil eye that should be avoided. In turn, could it be that she had an evil eye that did not see the compassion in the vineyard owner's generosity but identified with the first-comers' sense of unfairness in the latecomers' getting what the first-comers had been promised?

When this Matthean evil eye encounters the face, can it recognize the epiphany of the Absolutely Other in it? The face, for Levinas (1996), is where both the transcendence and destitution of a being is manifested. He says, "[T]he epiphany of the Absolutely Other is a face by which the Other challenges and commands me through his nakedness, through his destitution. He challenges me from his humility and from his height" (p. 17). Levinas (1991) says that such an "epiphany of the face is ethical" (p. 199). Eonkyeong's father, as the possessor of the evil eye, was a "quasi-nothing" (p. 199) that Eonkyeong pushed aside by avoiding his eyes. When a person, or the Other is turned into a quasi-nothing, it is a destruction or murder of the being that is overpowered and resisted by the infinite, which 
is found in "the face of the Other, in the total nudity of his defenseless eyes, in the nudity of the absolute openness of the Transcendent" (Levinas, 1991, p. 199). Here, the suffering Levinas wants us to recognize and prevent is what Rogers-Vaughn (2016) named the second order of suffering, "distress produced by human evil, whether individual or collective, direct or indirect" (p. 126) ${ }^{10}$ Suffering of this kind is identifiable and resistible, precisely what Levinas attempts in his philosophical work. However, what Eonkyeong's family had gone through was difficult to name; thus, the blame and resistance turned toward the family members themselves. This suffering, Rogers-Vaughn observes, is that of the third order (pp. 126-127), ${ }^{11}$ which is entangled with the first and second orders yet is difficult to pinpoint because it is the very structural mode in which we live in the neoliberal world. When the source of injury is unidentifiable, the evil eye turns inward. In facing the second order of suffering, Levinas asks everyone, including the perpetrator who causes the suffering, to look into the face of the Other and recognize the transcendent Absolutely Other, perhaps the divine, and thus feel responsibility toward them. Under the duress of third-order suffering, what should we look into? Just as the "comprehension of this destitution and this hunger establishes the very proximity of the other" (p. 200) for the second-order suffering that Levinas addresses, can the third-order suffering be diminished and bring those who are isolated by neoliberal rationality to a deeper understanding of such pain?

\section{Conclusion}

In her search for an answer, Eonkyeong looked into her father's eyes. For a brief moment after his new employer's call from Kazakhstan, she had this opportunity at home, face-toface, and then he hurriedly packed up and left for work. The encounters deepened as her family members more urgently looked into each other's faces on FaceTime. "What do you see in his face?" I asked, and Eonkyeong answered, "that he loves me, he trusts in me, and he is proud of me." In his face, she now sees his strength in maintaining hope despite his bleak reality. ${ }^{12}$ Now, she sees that he had become a great cook and a househusband, taking care of the details at home when she came back to collapse and rest. Before, his face was painfully challenging to look at. Now, she sees that she had been missing much. At her workplace, she had asked herself, "What would be the most pastoral thing to do in this predatory environment?" She had decided to greet everyone with a smile on her face, even

\footnotetext{
${ }^{10}$ First-order suffering stems from natural human conditions-death, grief, separation, illness, natural calamities, conflicts, etc.

11 True to the character of paradigm change, third-order suffering - the new normal for human distress appearing under neoliberalism - is not easy to articulate, perhaps impossible to articulate, in terms of firstand second-order suffering. Without strong, vibrant collectives to support them, individuals are more or less left to their own devices to deal with distress. We might describe them as in a state of spiritual homelessness. These unfortunate souls are abandoned, left to interpret their sufferings as signs of personal failure. They are not guilty. They are ashamed. They do not have adequate narrative resources at hand to understand, to "make sense of" their sufferings. They are left simply with market-generated narratives of "personal recovery," which, like insulin for the diabetic, are perpetually fragile in the face of what they are up against. Their oppressors, for example, no longer have faces, even the impersonal "faces" of the state, the corporation, or the church. Yet, to say the oppressor is some abstract "evil" seems not to capture the thing. Their options are either to look within, blaming their suffering on themselves, or to stare into the fog.

12 We note how powerful this strength is, especially when the patriarchal burden to earn a living often weighs hard on fathers. As we noted earlier, the heightened suicide rate of middle-aged men during financial crises testifies to the psychic pain that the patriarchal expectation forced Eonkyeong's father to endure.
} 
if it only showed in her eyes due to her mask. This awkward ritual slowly led to responses from those around her. Encounters with the eyes of her co-workers and superiors began to happen. Her wisdom called for face-to-face moments when she was drowning in thirdorder suffering.

We return to our original question: What is pastoral care amid the pandemic? This question required an eschatological search for hope in the midst of hopelessness. Eonkyeong only came to see the hope her father was holding after he was re-employed. Her co-workers were still working for the predatory company, grinding their bones in the capitalistic machine. Amid neoliberal third-order suffering, Rogers-Vaughn (2016) once noted, "[T]he currently prevailing practices of psychotherapy" have become "sophisticated exercises in blaming the victim"(p. 6). However, when Eonkyeong found what she had been missing in her father's face, she came back to me as urgently as she did when she had first come, saying, "Pastoral care should be about looking into the eyes of the Other. There is so much in them." Encountering the Other face-to-face overcomes the shame. Eonkyeong says, "Looking into his eyes was like encountering the divine, a sad and agonizing experience. Then hope appeared."

The dialogical journey we took was a journey to recover faces. Eonkyeong reflects, "The pain I encountered was faceless and unaccountable. The pain called for an explanation, which led me to blame my father." The combined process of storytelling and deep listening that led to our research and reflection was a process of uncovering the face of neoliberalism. The process of putting our collaborative reflection in writing was also a therapeutic process for Eonkyeong, as she was gaining mirrors to look into both me as her listener and the finished article that went through three layers of translations, from her language to mine, from spoken to written, and then from Korean to English, each translation adding more perspectives. This mirror-gazing process also accelerated when the subjectivity of the Bible participated in our dialogue. The deeper layers of meaning, excavated in our exegetic conversation, allowed us to look behind the conventional interpretation we were used to and opened our visual horizon behind the faceless suffering. When our interpretation was reflected against the mirror of the Bible, the answers we gained from the Bible allowed our perspective to change in a drastic way. ${ }^{13}$ The subjectivity of the Bible thus provided critical and spiritual plots for navigating the existential challenges posed by the pandemic.

It should be noted that the prospect of making Eonkyeong's story public, albeit to the relatively small audience of readers of an academic journal, added another layer of motivation. Each page we wrote sparked a certain joy in us. However, it also came with a price. We read this paper in a master-level class to get other students' feedback, and one of the responses was heartbreaking for Eonkyeong. An older female student commented that if Eonkyeong were a bit more seasoned in life, she would not have blamed but would have understood her father. We had to recoup. Our reflection together revealed that such a guilt-producing narrative again stems from the dynamic of neoliberal rationality we had unearthed in this paper. This process also highlighted that the struggle during the pandemic has not ended with the conclusion we draw in this paper. Thus, the adventure of jumping over the line of confidentiality and proactively making our conversation public exposed the vulnerability in our choice.

\footnotetext{
13 I noted in my dissertation, Park (2014), that research participants experienced drastic change in perspectives when the subjectivity of the Bible provided piercing answers to the questions they had wrestled with in their lives (p. 88). Such experiences of transformation can be theorized through the concept of mutual empathy from relational cultural theory and the Confucian spirituality of the movement of the heart, which I explored in my work.
} 
However, we both think this was a worthwhile attempt. For me as her teacher, it was an effective way to convey the reality of the intangible and spectral processes of neoliberal suffering in the most concrete lived experience of the COVID-19 pandemic that was unfolding in her life. Such invisible processes are often difficult to name in the counseling room because they require extensive explanation and exploration. For Eonkyeong, our exploration was a form of care. She states in her concluding reflection, "To me, this dialogical research journey with my professor was in itself another form of pastoral care."

Funding This study was funded by a 2020 Ewha Womans University Research grant. The two authors have no conflicts of interest. This article does not contain any studies with human participants performed by any of the authors.

\section{References}

Brown, W. (2015). Undoing the demos: Neoliberalism's stealth revolution. Zone Books.

Buber, M. (1996). I and thou (W. Kaufmann, Trans.). Touchstone.

Chang, K.-S. (2018). The end of tomorrow? Familial liberalism and social reproduction crisis. Jipmoondang.

Davies, W. (2016). The new neoliberalism. New Left Review, 101. https://newleftreview.org/issues/ii101/ articles/william-davies-the-new-neoliberalism

Elliott, J. (1992). Matthew 20:1-15: A parable of invidious comparison and evil eye accusation. Biblical Theology Bulletin, 22(2), 52-65.

Graeber, D. (2014). Debt: The first 5,000 years. Melville House.

Kim, M.-Y., Chŏng, K.-H., \& Kum, H. (2011). Kyŏngjewigiwa Jasalyul Kan T’amsaekjŏk Yŏngu [Exploratory study of the relationship between the financial crisis and the suicide rate]. Korean Journal of Policy Analysis and Evaluation, 21(3), 273-302.

Kotsko, A. (2018). Neoliberalism's demons: On the political theology of late capital. Stanford University Press.

Lazzarato, M. (2012). The making of the indebted man: An essay on the neoliberal condition (J. Jordan, Trans.). Semiotext(e).

Levinas, E. (1991). Totality and infinity (A. Lingis, Trans.). Kluwer Academic Publishers.

Levinas, E. (1996). Transcendence and height. In A. Peperzak, S. Critchley, \& R. Bernasconi (Eds.), Emmanuel Levinas: Basic philosophical writings (pp. 11-31). Indiana University Press.

Park, H.-K. (2014). Lamp to my feet, light to my path: Understanding biblical engagement for transformation. Claremont School of Theology.

Reilly, R. (2010). Participatory case study. In A. Mills, G. Durepos, \& E. Wiebe (Eds.). Encyclopedia of Case Study Research, 2, 658-661. Sage Publications.

Rogers-Vaughn, B. (2016). Caring for souls in a neoliberal age. Palgrave Macmillan.

Sassen, S. (2014). Expulsions: Brutality and complexity in the global economy. Belknap Press of Harvard University Press.

Publisher's note Springer Nature remains neutral with regard to jurisdictional claims in published maps and institutional affiliations. 